\title{
Deleterious FANCA Gene Mutation
}

National Cancer Institute

\section{Source}

National Cancer Institute. Deleterious FANCA Gene Mutation. NCI Thesaurus. Code C150149.

A change in the nucleotide sequence of the FANCA gene that is associated with increased risk of disease. 